

\title{
ANALISIS RASIO AKTIVITAS DAN PROFITABILITAS UNTUK MENILAI KINERJA KEUANGAN PT. FAST FOOD INDONESIA, Tbk TAHUN 2011 s.d 2015
}

\author{
WaluyoJati \\ StafPengajarFakultasEkonomiUniversitasPamulang \\ Email :waluyojati21@yahoo.com \\ Ida \\ Alumnus FakultasEkonomiUniversitasPamulang
}

\begin{abstract}
ABSTRAK
Penelitian ini bertujuan untuk mengetahui rasio aktivitas dan profitabilitas PT. Fast Food Indonesia, Tbk tahun 2011 sampai dengan 2015 serta untuk mengetahui kinerja keuangan PT Fast Food IndonesiaTbk tahun 2011 sampai dengan 2015.

Metode yang digunakan dalam penelitian ini adalah metode kuantitatif dengan pendekatan deskriptif. Data penelitian yang digunakan merupakan data sekunder berupa laporan keuangan perusahaan yang telah dipublikasikan oleh Bursa Efek Indonesia (BEI). Metode analisis data menggunakan analisis rasio pada laporan neraca dan laporan laba rugi, dengan indikator yang digunakan adalah Working Capital Turn Over (WCTO) dan Total Assets Turn Over (TATO) untuk rasio aktivitas serta Gross Profit Margin (GPM), Net Profit Margin (NPM), Return on Investment (ROI) dan Return on Equity (ROE) untuk rasio profitailitas.

Hasil penelitian menunjukkan bahwa rasio aktivitas PT. Fast Food Indonesia,Tbk tahun 2011 sampai dengan 2015 untuk WCTO perusahaan mengalami kenaikan yaitu berturut-turut 4,2 kali, 4,4 kali, 4,3 kali, 4,5 kali, dan 4,5 kali. Sedangkan TATO perusahaan mengalami penurunan yaitu diketahui berturut-turut 2,1 kali, 2 kali, 2 kali, 1,9 kali, dan 1,9 kali. Rasio Profitabilitas PT. Fast Food Indonesia tahun 2011 s.d 2015 mengalami kenaikan dan penurunan. Indikator GPM diketahui berturut-turut 58,9\%, 58,5\%, 59,3\%, 60,4\% dan 60,9\%. NPM diketahui berturut-turut 7,2\%, 5,8\%, 3,9\%, 3,7\%, dan 2,3\%. ROI diketahui berturut-turut $14,8 \%, 11,6 \%, 7,7 \%, 7,2 \%$, dan 4,5\%. Sedangkan ROE diketahui berturut-turut $27,6 \%, 20,8 \%, 15,9 \%, 14,8 \%$, dan 9,4\%. Kinerja Keuangan PT. Fast Food Indonesia Tbk tahun 2011 s.d 2015 berdasarkan rasio aktivitas dikatakan baik karena berada di atas rata-rata industri. Sedangkan berdasarkan rasio profitabilitas kinerja keuangan PT. Fast Food Indonesia Tbk tahun 2011 s.d 2015 dikatakan kurang baik karena berada di bawah rata-rata industri.
\end{abstract}

Kata kunci : Rasio Aktivitas, Rasio Profitabilitas, dan Kinerja Keuangan

\section{ABSTRACT}

This research's purpose is to reveal activity ratio and profitability of PT. Fast Food Indonesia Tbk, from 2011 until 2015, as well as to reveal the company's financial performance from 2011 until 2015.

The method used for this research is quantitative method with descriptive approach. Data for this research are secondary data which are the company's 


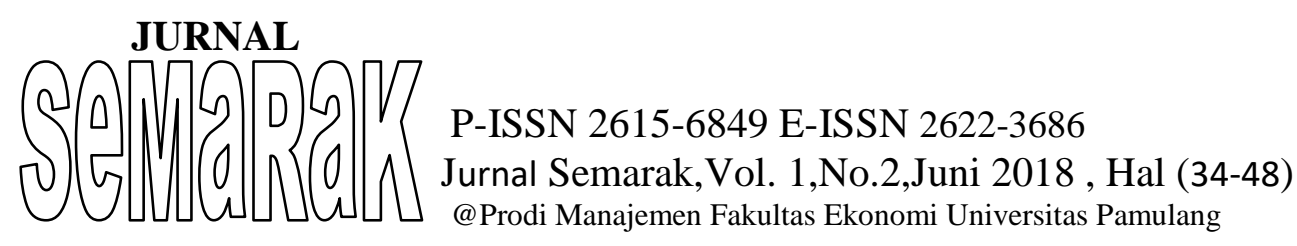

financial report published by Bursa Efek Indonesia (BEI). Data analyzing method are ratio analysis for balance statement and profit and loss statement, while indicator used for activity ratio are WCTO and TATO, and GPM, NPM, ROI, and ROE, for the profitability ratio.

This research shows that PT. Fast Food Indonesia Tbk's activity ratio from 2011 until 2015 experiences an increases in its company's WCTO which are 4.2 times, 4.4 times, 4.3 times, 4.5 times, and 4.5 times respectively. Meanwhile, its TATO decreases 2.1 times, 2.0 times, 2.0 times, 1.9 times and 1.9 times respectively. The company's profitability ratio from 2011 until 2015 experienced an increase and decrease in GPM indicator for $58.9 \%, 58.5 \%, 59.3 \%, 60.4 \%$ and $60.9 \%$ respectively. NPM is revealed as $7.2 \%, 5.8 \%, 3.2 \%, 3.7 \%$ and $2.3 \%$ respectively, while ROI was $14.8 \%, 11.6 \%, 7.7 \%, 7.2 \%$, and $4.5 \%$ respectively and ROE are $27.6 \%, 20.8 \%, 15.9 \%, 14.8 \%$ and $9.4 \%$ respectively. PT Fast Food Indonesia Tbk's financial performance from 2011 to 2015, based on its activity ratio, is considered good due to be in above average level of the industry. Meanwhile, based on profitability ratio, PT Fast Food Indonesia Tbk's financial performance from 2011 to 2015 its not good, because it is below of the industry's average level.

Keywords: Activity Ratio, Profitability Ratio, Financial Performance.

\section{PENDAHULUAN}

\section{A. Latar Belakang}

Peran perusahaan telah memberikan kontribusi yang besar terhadap pertumbuhan ekonomi Indonesia. Nyatanya, pada tahun 2013 berdasarkan data Kementerian Koperasi dan UKM menyebutkan bahwa kontribusi BUMN terhadap produk domestik bruto (PDB) hanya sebesar 20 persen. Sedangkan 78 persennya disumbangkan oleh sektor swasta (UKM dan perusahaan besar) dan 2 persen oleh sektor koperasi.

Dari laporan keuangan yang telah disajikan, maka dapat dinilai kinerja keuangan perusahaan tersebut. Penilaian kinerja keuangan perusahaan dapat dianalisis dengan menggunakan rasio-rasio keuangan, diantaranya rasio likuiditas, rasio solvabilitas, rasio aktivitas, dan rasio profitabilitas.

Rasio likuiditas (liquidity ratio) merupakan rasio yang menggambarkan kemampuan perusahaan dalam memenuhi kewajiban jangka pendek. Rasio solvabilitas (Leverage Ratio) merupakan rasio yang digunakan untuk mengukur sejauh mana aktiva perusahaan dibiayai dengan utang. Rasio aktivitas (activity ratio) merupakan rasio yang digunakan untuk mengukur tingkat efisiensi pemanfaatan sumber daya perusahaan (penjualan, sediaan, penagihan piutang, dan lainnya) atau rasio untuk menilai kemampuan perusahaan dalam melaksanakan aktivitas sehari-hari. Sedangkan rasio profitabilitas (profitability ratio) merupakan rasio untuk menilai kemampuan perusahaan dalam mencari keuntungan atau laba dalam suatu periode tertentu, juga memberikan ukuran tingkat efektivitas manajemen suatu perusahaan yang ditunjukan dari laba yang dihasilkan dari penjualan atau dari pendapatan investasi (Kasmir:2016).

Penilaian kinerja keuangan dengan menggunakan analisis rasio dapat digunakan untuk berbagai jenis industri. Tidak menutup kemungkinan diterapkan untuk menilai kinerja keuangan industri makanan cepat saji seperti halnya PT. Fast Food Indonesia, Tbk.

PT. Fast Food Indonesia, Tbk merupakan perusahaan yang telah Go 


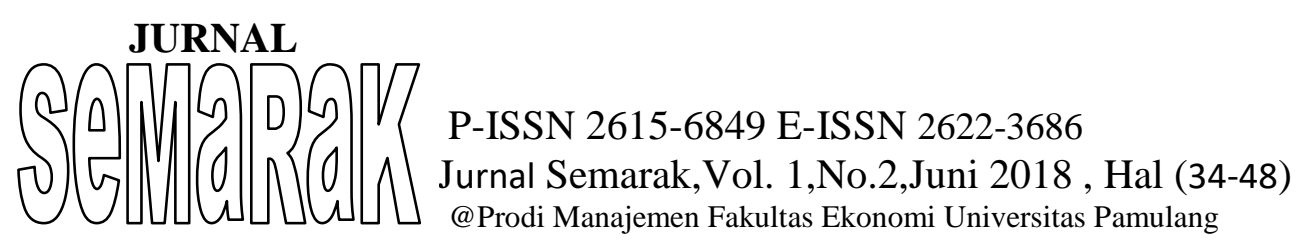

Public dimana perusahaan ini merupakan pemegang hak waralaba tunggal untuk merek KFC di Indonesia. Perusahaan ini didirikan oleh Keluarga Gelael pada tahun 1978 dan sejak berdiri hingga akhir tahun 2016 perusahaan pemegang lisensi KFC ini memiliki lebih dari 575 gerai yang tersebar di seluruh daerah di Indonesia.

PT. Fast Food Indonesia, Tbk seperti halnya perusahaan-perusahaan lain pada umumnya memiliki tujuan yang sama yaitu memperoleh laba/ profit dan meningkatkan nilai perusahaan. Namun ditengah-tengah berbagai upaya setiap perusahaan yang berjuang menghadapi kondisi persaingan yang ada, dalam hal ini PT. Fast Food Indonesia Tbk harus berjuang di tengah persaingan dengan bertambah banyaknya perusahaan makanan cepat saji, serta kondisi sosial dan ekonomi, PT. Fast Food Indonesia telah mengalami grafik pertumbuhan yang sama dengan pertumbuhan ekonomi Indonesia, dimana perusahaan mengalami penurunan tingkat pencapaian laba.

Salah satu alat analisis yang lazim digunakan dalam menilai kinerja keuangan sebuah perusahaan adalah dengan menggunakan analisis rasio keuangan. Adapun berdasarkan gejala yang ada yaitu penurunan laba makaC. teknik analisis yang dapat digunakan adalah analisis rasio profitabilitas, yaitu untuk mengukur tingkat efektivitas manajemen suatu perusahaan yang ditunjukan dari laba yang dihasilkan. Selain analisis rasio profitabilitas, dapat juga dilakukan dengan analisis rasio aktivitas, yaitu untuk mengukur tingkat efisiensi pemanfaatan sumber daya perusahaan.

Berdasarkan pemaparan dan data diatas mengenai laporan keuangan

PT. Fast Food Indonesia Tbk, maka penulis tertarik untuk meneliti permasalahanmengenai"Analisis Rasio Aktivitas dan Profitabilitas untuk Menilai Kinerja Keuangan PT. Fast Food Indonesia Tbk, tahun 2011 sd 2015."

B. Identifikasi Masalah.

1. Penurunan laba bersih secara terus menerus dari tahun 2011 sampai dengan tahun 2015. Hal ini menunjukan kemampuan perusahaan dalam menghasilkan laba (profitabilitas) semakin menurun.

2. Beban usaha PT. Fast Food Indonesia Tbk mengalami kenaikan secara terus menerus. Hal ini ditunjukan dengan pendapatan perusahaan dari tahun 2011 s.d 2015 yang terus meningkat, namun penerimaan laba bersih terus menurun.

3. Beban usaha yang terus meningkat mengindikasikan perusahaan belum maksimal dalam melakukan efisiensi.

4. Penurunan laba dan kenaikan beban secara terus menerus mengindikasikan penurunan kinerja keuangan perusahaan.

\section{Batasan Masalah}

1. Rasio Aktivitas

Menurut Kasmir (2016:172) Rasio Aktivitas merupakan rasio yang digunakan untuk mengukur efektivitas perusahaan dalam menggunakan aktiva yang dimilikinya. Dari hasil pengukuran dengan rasio aktivitas akan terlihat apakah perusahaan lebih efisien dan efektif dalam mengelola asset yang dimilikinya atau mungkin justru sebaliknya. Dalam penelitian ini 


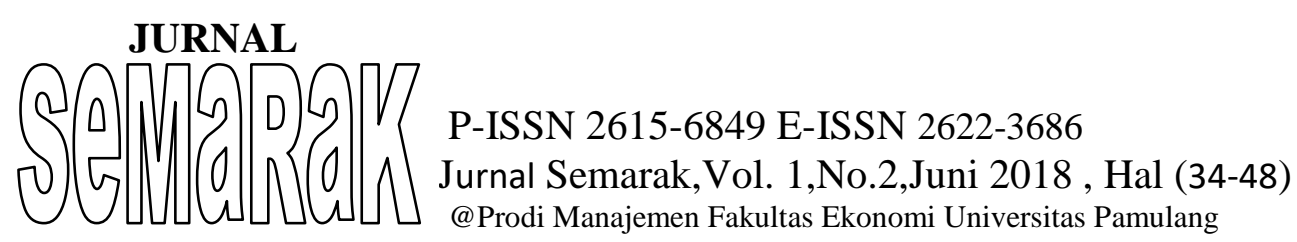

rasio aktivitas digunakan untuk mengukur kinerja keuangan perusahaan. Adapun rasio aktivitas yang digunakan sebagai teknik analisis dalam penelitian ini adalah rasio perputaran modal kerja (working capital turn over) dan rasio perputaran total aktiva (total assets turn over).

2. Rasio Profitabilitas

Menurut Kasmir (2016:196) Rasio Profitabiliitas atau dikenal juga dengan nama rasio rentabilitas merupakan rasio untuk menilai kemampuan perusahaan dalam mencari keuntungan. Rasio profitabilitas dalam penelitian ini juga digunakan untuk menilai kinerja keuangan perusahaan. Adapun rasio yang digunakan sebagai teknik analisis antara lain Gross Profit Margin (GPM),Net Profit Margin (NPM), Return on Investment (ROI) dan Return on Equity (ROE).

3. Kinerja Keuangan

Yang dimaksud dengan kinerja keuangan adalah hasil dari pencapaian perusahaan yang diukur dengan efektivitas atas aktivitas manajemen keuangan perusahaan dan kemampuan perusahaan dalam menghasilkan keuntungan pada periode tertentu.

4. Objek Penelitian

Objek pada penelitian ini adalah PT. Fast Food Indonesia Tbk, dengan data yang diamati adalah laporan keuangan perusahaan tahun 2011 sampai dengan tahun 2015. PT. Fast Food Indonesia Tbk merupakan perusahaan yang bergerak di bidang industri restoran makanan cepat saji, dimana perusahaan merupakan pemegang

hak tunggal waralaba merek KFC di Indonesia.

\section{Rumusan Masalah}

1. Bagaimana rasio aktivitas PT. Fast Food Indonesia Tbk tahun 2011 s.d 2015?

2. Bagaimana rasio profitabilitas PT. Fast Food Indonesia Tbk tahun 2011 s.d 2015?

3. Bagaimana kinerja keuangan PT. Fast Food Indonesia Tbk berdasarkan rasio aktivitas dan rasio profitabilitas pada tahun 2011 s.d 2015?

\section{E. Tujuan Manfaat Penelitian}

1. Penulis ingin mengetahui rasio aktivitas PT. Fast Food Indonesia Tbk tahun 2011 s.d 2015;

2. Penulis ingin mengetahui rasio profitabilitas PT. Fast Food Indonesia Tbk tahun 2011 s.d 2015;

3. Penulis ingin mengetahui kinerja keuangan PT. Fast Food Indonesia Tbk pada tahun 2011 s.d 2015 dengan menggunakan penilaian rasio aktivitas dan rasio profitabilitas.

\section{F. Hipotesis}

Menurut Sugiyono (2016:64) Hipotesis merupakan jawaban sementara terhadap rumusan masalah, dimana rumusan masalah penelitian telah dinyatakan dalam bentuk kalimat pertanyaan. Dikatakan sementara, karena jawaban yang diberikan baru didasarkan teori, belum didasarkan pada fakta-fakta empiris yang diperoleh melalui pengumpulan data. 


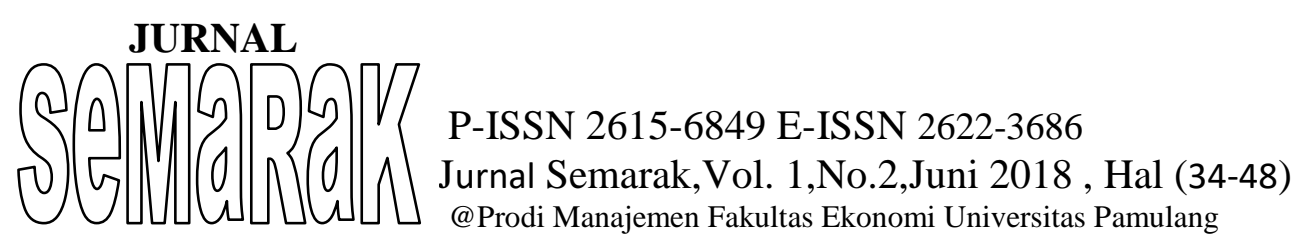

Adapun pada penelitian ini penulis membuat suatu hipotesis bahwa "Kinerja keuangan PT. Fast Food Indonesia Tbk belum baik bila ditinjau dari rasio aktivitas dan profitabilitas".

\section{TINJAUAN PUSTAKA}

A. Manajemen Keuangan

Menurut Erni Ekawati (2009:1.7), terdapat tiga macam bentuk perusahaan yaitu perusahaan perseorangan (sole proprietorship), perusahaan persekutuan (partnership) dan perseroan terbatas (corporation). Dilihat dari sisi jumlah perusahaan, bentuk perusahaan perseorangan mendominasi kegiatan perekonomian di berbagai Negara, tetapi dari sisi jumlah nilai penjualannya bentuk perseroan terbatas yang paling dominan. Bentuk perseroan terbatas ini memisahkan antara pengelola perusahaan (manajer) dan pemilik perusahaan (pemegang saham). Maka semua konsep manajemen keuangan akan mendasarkan pembahasannya dengan menggunakan bentuk perseroan terbatas. Akan tetapi tidak menutup kemungkinan bahwa konsepkonsep tersebut tetap dapat dipakai bahkan lebih sederhana bila diterapkan pada bentuk perusahaan yang lain.

\section{B. Laporan Keuangan}

Laporan Keuangan merupakan kewajiban setiap perusahaan untuk membuat dan melaporkannya pada suatu periode tertentu. Laporan keuangan yang dikeluarkan perusahaan dapat dijadikan sumber informasi yang sangat penting dan dibutuhkan berbagai pihak seperti investor, kreditur, pemegang saham maupun pihak lainnya. Adapun beberapa pengertian laporan keuangan yang dikemukan oleh para ahli, diantaranya;

Menurut Kashmir (2016:7)

Laporan Keuangan adalah laporan yang menunjukkan kondisi keuangan perusahaan pada saat ini atau dalam suatu periode tertentu. Maksud dari laporan keuangan yang menujukkan kondisi perusahaan saat ini adalah merupakan kondisi terkini. Kondisi perusahaan terkini adalah keadaan keuangan perusahaan pada tanggal tertentu (untuk neraca) dan periode tertentu (untuk laporan laba rugi).

Menurut Sutrisno (2013:8) Laporan Keuangan merupakan hasil akhir dari proses akuntansi yang meliputi dua laporan utama yakni (1) Neraca (2) Laporan Rugi Laba.

\section{Analisis Laporan Keuangan}

Menurut Subramanyam (2017:15) analisis laporan keuangan merupakan kumpulan proses analitis yang merupakan bagian dari analisis bisnis. Sedangkan menurut Munawir dalam Nurhamdi (2015:34) analisa laporan keuangan terdiri dari penelaahan atau mempelajari daripada hubungan-hubungan dan tendensi atau kecendrungan (trend) untuk menentukan posisi keuangan dan hasil operasi serta perkembangan perusahaan bersangkutan.

\section{Analisis Rasio Keuangan}






\begin{abstract}
Analisis rasio menurut Hery (2017:139) adalah analisis yang dilakukan dengan menghubungkan berbagai perkiraan yang ada pada laporan keuangan dalam bentuk rasio keuangan. Analisis rasio keuangan ini dapat mengungkapkan hubungan yang penting antarperkiraan laporan keuangan dan dapat digunakan untuk mengevaluasi kondisi keuangan dan kinerja perusahaan.
\end{abstract}

\section{E. Rasio Aktivitas}

Menurut Irham Fahmi (2010:182) rasio aktivitas adalah rasio yang menggambarkan sejauh mana suatu perusahaan mempergunakan sumber daya yang dimilikinya guna menunjang aktivitas perusahaan.

Menurut Hery (2017:143) rasio aktivitas merupakan rasio yang digunakan untuk mengukur tingkat efisiensi atas pemanfaatan sumber daya yang dimiliki perusahaan atau untuk menilai kemampuan perusahaan dalam menjalankan aktivitasnya seharihari. Rasio ini dikenal juga sebagai rasio pemanfaatan aset, yaitu rasio yang digunakan untuk menilai efektivitas dan intensitas aset perusahaan dalam menghasilkan penjualan.

\section{F. Kinerja Keuangan}

\section{Pengertian Kinerja Keuangan}

Menurut Irham Fahmi (2010:2) kinerja adalah hasil yang diperoleh oleh suatu organisasi baik organisasi tersebut bersifat profit oriented dan non profit oriented yang dihasilkan selama satu periode waktu. Secara lebih tegas Amstron dan Baron dalam Irham Fahmi (2010:2) mengatakan Kinerja merupakan hasil pekerjaan yang mempunyai hubungan kuat dengan tujuan startegis organisasi, kepuasan konsumen dan memberikan kontribusi ekonomi. Chaizi Nasucha dalam Irham Fahmi (2010:3) mengemukakan bahwa kinerja organisasi adalah sebagai efektivitas organisasi secara menyeluruh untuk memenuhi kebutuhan yang ditetapkan dari setiap kelompok yang berkenaan dengan usaha-usaha yang sistematik dan meningkatkan kemampuan organisasi secara terus menerus mencapai kebutuhannya secara efektif.

\section{METODOLOGI PENELITIAN \\ A. Ruang Lingkup Penelitian.}

Dalam penelitian ini yang menjadi objek penelitian adalah kinerja keuangan PT. Fast Food Indonesia Tbk periode 2011 sampai dengan 2015. PT. Fast Food Indonesia Tbk merupakan perusahaan yang bergerak dalam industri restoran cepat saji yaitu pemegang waralaba tunggal merek KFC di Indonesia. PT. Fast Food Indonesia Tbk memiliki kantor pusat yang beralamat di Jalan MT Haryono Kav 7 Gedung Galael, Tebet Barat Jakarta Selatan.

Dalam penelitian ini penulis melakukan riset di Pusat Referensi Pasar Modal (PRPM) - Bursa Efek Indonesia (BEI) yang beralamat di Jalan Jenderal Sudirman Kav. 52-53 Jakarta. Adapun waktu penelitian ini dilakukan selama 4 (empat) 
bulan yaitu pada bulan Juni sampai dengan September 2017.

\section{B. Populasi dan Penentuan Sampel \\ 1. Populasi}

Adapun populasi dalam penelitian ini adalah Laporan Keuangan PT. Fast Food Indonesia, Tbk.

\section{Sampel}

Sampel penelitian ini adalah laporan neraca dan laporan laba rugi PT. Fast Food Indonesia Tbk tahun 2011 s.d 2015.

\section{Metode Analisis Data}

Adapun metode analisis data dalam penelitian ini menggunakan metode analisis rasio keuangan yaitu rasio aktivitas dan rasio profitabilitas. Dengan analisis rasio ini penulis dapat membandingkan keadaan perusahaan dari satu periode ke periode lainnya sehingga dapat diketahui peningkatan atau penurunan kinerja keuangan perusahaan. Selain itu, dengan analisis rasio ini penulis juga membandingkan keadaan perusahaan dengan perusahaan lainnya.

\section{PEMBAHASAN DAN HASIL PENELITIAN}

\section{Rasio Aktivitas PT. Fast Food Indonesia, Tbk.}

\section{a.Perputaran Modal Kerja}

(Working Capital Turn Over)

Perhitungan Working Capital Turn

OverPT. Fast Food Indonesia, Tbk.

Tahun 2011 s.d 2015

(dalam jutaan rupiah)

\begin{tabular}{|c|c|c|c|c|}
\hline \multicolumn{2}{|r|}{ (4)стит } & \multicolumn{3}{|c|}{ 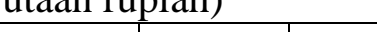 } \\
\hline $\begin{array}{c}\text { TAHU } \\
\mathrm{N}\end{array}$ & $\begin{array}{l}\text { PENJUALAN } \\
\text { (a) }\end{array}$ & $\begin{array}{l}\text { AKTIVA } \\
\text { LANCAR } \\
\text { (b) }\end{array}$ & $\begin{array}{c}\text { WCTO } \\
(\mathrm{a} / \mathrm{b})\end{array}$ & $\begin{array}{c}\text { RATA } \\
- \\
\text { RATA }\end{array}$ \\
\hline 2011 & 3.183 .815 & 758.699 & 4,2 & \multirow{5}{*}{$\begin{array}{l}4,4 \\
\text { kali }\end{array}$} \\
\hline 2012 & 3.559 .485 & 802.840 & 4,4 & \\
\hline 2013 & 3.960 .253 & 912.655 & 4,3 & \\
\hline 2014 & 4.208 .887 & 939.720 & 4,5 & \\
\hline 2015 & 4.475 .061 & 996.745 & 4,5 & \\
\hline
\end{tabular}

b. Perputaran Total Aset (Total Assets Turn Over)

Perhitungan Total Assets Turn Over

PT. Fast Food Indonesia, Tbk.

Tahun 2011 s.d 2015

(dalam jutaan rupiah)

\begin{tabular}{|c|c|c|c|c|}
\hline TAHUN & $\begin{array}{l}\text { PENJUALAN } \\
\text { (a) }\end{array}$ & $\begin{array}{l}\text { TOTAL } \\
\text { ASSET } \\
\text { (b) }\end{array}$ & $\begin{array}{c}\text { TATO } \\
(\mathrm{a} / \mathrm{b})\end{array}$ & $\begin{array}{l}\text { RATA- } \\
\text { RATA }\end{array}$ \\
\hline 2011 & 3.183 .815 & 1.547 .982 & $\begin{array}{l}2,1 \\
\text { kali }\end{array}$ & \multirow{5}{*}{2 kali } \\
\hline 2012 & 3.559 .485 & 1.781 .906 & $\begin{array}{l}2,0 \\
\text { kali }\end{array}$ & \\
\hline 2013 & 3.960 .253 & 2.028 .125 & $\begin{array}{l}2,0 \\
\text { kali }\end{array}$ & \\
\hline 2014 & 4.208 .887 & 2.162 .634 & $\begin{array}{l}1,9 \\
\text { kali }\end{array}$ & \\
\hline 2015 & 4.475 .061 & 2.310 .536 & $\begin{array}{l}1,9 \\
\text { kali }\end{array}$ & \\
\hline
\end{tabular}

2. Rasio Profitabilitas PT. Fast Food Indonesia, Tbk.

a. Gross Profit Margin (GPM)

Perhitungan Gross Profit

MarginPT. Fast Food Indonesia, Tbk.Tahun 2011 s.d 2015

\begin{tabular}{|c|c|c|c|c|c|}
\hline $\begin{array}{c}\text { TA } \\
\text { HU } \\
\mathrm{N}\end{array}$ & $\begin{array}{l}\text { PENJUA } \\
\text { LAN } \\
\text { (a) }\end{array}$ & $\begin{array}{l}\text { HPP } \\
\text { (b) }\end{array}$ & $\begin{array}{c}\text { LABA } \\
\text { KOTOR } \\
(\mathrm{c}=\mathrm{a}-\mathrm{b})\end{array}$ & $\begin{array}{c}\text { GPM } \\
(\mathrm{d}=\mathrm{c} / \mathrm{a}) * \\
100 \%\end{array}$ & $\begin{array}{l}\text { RA } \\
\text { TA- } \\
\text { RA } \\
\text { TA }\end{array}$ \\
\hline $\begin{array}{c}201 \\
1\end{array}$ & $\begin{array}{c}3.183 .81 \\
5\end{array}$ & $\begin{array}{c}1.307 . \\
042\end{array}$ & 1.876 .773 & $58,9 \%$ & \multirow{5}{*}{$\begin{array}{c}59,6 \\
\%\end{array}$} \\
\hline $\begin{array}{c}201 \\
2\end{array}$ & $\begin{array}{c}3.559 .48 \\
5\end{array}$ & $\begin{array}{c}1.476 . \\
700\end{array}$ & 2.082 .785 & $58,5 \%$ & \\
\hline $\begin{array}{c}201 \\
3\end{array}$ & $\begin{array}{c}3.960 .25 \\
3\end{array}$ & $\begin{array}{c}1.610 . \\
838\end{array}$ & 2.349 .415 & $59,3 \%$ & \\
\hline $\begin{array}{c}201 \\
4\end{array}$ & $\begin{array}{c}4.208 .88 \\
7\end{array}$ & $\begin{array}{c}1.666 . \\
317\end{array}$ & 2.542 .570 & $60,4 \%$ & \\
\hline $\begin{array}{c}201 \\
5\end{array}$ & $\begin{array}{c}4.475 .06 \\
1\end{array}$ & $\begin{array}{c}1.751 . \\
378\end{array}$ & 2.723 .683 & $60,9 \%$ & \\
\hline
\end{tabular}

b. Net Profit Margin (NPM)

Perhitungan Net Profit Margin

PT. Fast Food Indonesia, Tbk.

Tahun 2011 s.d 2015

(dalam jutaan rupiah)

\begin{tabular}{|c|c|c|c|c|}
\hline $\begin{array}{c}\text { TAH } \\
\text { UN }\end{array}$ & $\begin{array}{c}\text { PENJU } \\
\text { ALAN } \\
\text { (a) }\end{array}$ & $\begin{array}{c}\text { LABA } \\
\text { BERSIH } \\
\text { (b) }\end{array}$ & $\begin{array}{c}\text { NPM } \\
\text { (b/a)*1 } \\
00 \%\end{array}$ & $\begin{array}{l}\text { RATA- } \\
\text { RATA }\end{array}$ \\
\hline 2011 & $\begin{array}{c}3.183 .81 \\
5\end{array}$ & 229.054 & $7,2 \%$ & \multirow{5}{*}{$4,6 \%$} \\
\hline 2012 & $\begin{array}{c}3.559 .48 \\
5\end{array}$ & 206.046 & $5,8 \%$ & \\
\hline 2013 & $\begin{array}{c}3.960 .25 \\
3\end{array}$ & 156.291 & $3,9 \%$ & \\
\hline 2014 & $\begin{array}{c}4.208 .88 \\
7\end{array}$ & 156.049 & $3,7 \%$ & \\
\hline 2015 & $\begin{array}{c}4.475 .06 \\
1\end{array}$ & 105.024 & $2,3 \%$ & \\
\hline
\end{tabular}


c. Return on Investment (ROI)

Perhitungan Return on

Investment (ROI)

PT. Fast Food Indonesia, Tbk.

Tahun 2011 s.d 2015

(dalam jutaan rupiah)

\begin{tabular}{|c|c|c|c|c|}
\hline $\begin{array}{c}\text { TA } \\
\text { HU } \\
\mathrm{N}\end{array}$ & $\begin{array}{l}\text { TOTAL } \\
\text { ASET } \\
\text { (a) }\end{array}$ & $\begin{array}{c}\text { LABA } \\
\text { BERSIH } \\
\text { (b) }\end{array}$ & $\begin{array}{c}\text { ROI } \\
\text { (b/a)*1 } \\
00 \%\end{array}$ & $\begin{array}{l}\text { RA } \\
\text { TA- } \\
\text { RA } \\
\text { TA }\end{array}$ \\
\hline $\begin{array}{c}201 \\
1\end{array}$ & 1.547 .982 & 229.054 & $14,8 \%$ & \multirow{5}{*}{$\begin{array}{c}9,2 \\
\%\end{array}$} \\
\hline $\begin{array}{c}201 \\
2\end{array}$ & 1.781 .906 & 206.046 & $11,6 \%$ & \\
\hline $\begin{array}{c}201 \\
3\end{array}$ & 2.028 .125 & 156.291 & $7,7 \%$ & \\
\hline $\begin{array}{c}201 \\
4\end{array}$ & 2.162 .634 & 156.049 & $7,2 \%$ & \\
\hline $\begin{array}{c}201 \\
5\end{array}$ & 2.310 .536 & 105.024 & $4,5 \%$ & \\
\hline
\end{tabular}

d. Return on Equity (ROE)

Perhitungan Return on Equity

(ROE)PT. Fast Food Indonesia,

Tbk.Tahun 2011 s.d 2015

(dalam jutaan rupiah)

\begin{tabular}{|c|c|c|c|c|}
\hline $\begin{array}{c}\text { TA } \\
\text { HU } \\
\text { N }\end{array}$ & $\begin{array}{c}\text { EKUIT } \\
\text { AS } \\
\text { (a) }\end{array}$ & $\begin{array}{c}\text { LABA } \\
\text { BERSIH } \\
\text { (b) }\end{array}$ & $\begin{array}{c}\text { ROE } \\
\text { (b/a)*1 } \\
00 \%\end{array}$ & $\begin{array}{c}\text { RATA } \\
\text { RATA }\end{array}$ \\
\hline 2011 & 830.718 & 229.054 & $27,6 \%$ & \\
\cline { 1 - 4 } 2012 & 990.723 & 206.046 & $20,8 \%$ & \\
\cline { 1 - 4 } 2013 & 984.968 & 156.291 & $15,9 \%$ & \multirow{2}{*}{$17,7 \%$} \\
2014 & $\begin{array}{c}1.051 .0 \\
66\end{array}$ & 156.049 & $14,8 \%$ & \\
\cline { 1 - 4 } 2015 & $\begin{array}{c}1.114 .9 \\
17\end{array}$ & 105.024 & $9,4 \%$ & \\
\cline { 1 - 3 }
\end{tabular}

\section{Perbandingan Hasil Analisis} Rasio Aktivitas dan Profitabilitas dalam Menilai Kinerja Keuangan Perusahaan dengan Rata-rata Industri

Rasio Rata-rata Industri

Restoran Makanan Cepat Saji

Tahun 2011 s.d 2015

\begin{tabular}{|c|c|c|c|c|c|c|}
\hline \multirow{2}{*}{ Tahun } & \multicolumn{2}{|c|}{ RASIO } & \multicolumn{4}{|c|}{ RASIO PROFITABILITAS } \\
\cline { 2 - 7 } & $\begin{array}{c}\text { WCT } \\
\text { O }\end{array}$ & TATO & $\begin{array}{c}\text { GP } \\
\text { M }\end{array}$ & $\begin{array}{c}\text { NP } \\
\text { M }\end{array}$ & ROI & ROE \\
\hline \multirow{2}{*}{2011} & 4,6 & 2,1 & $\begin{array}{c}62,4 \\
\%\end{array}$ & $8,2 \%$ & $\begin{array}{c}17,6 \\
\%\end{array}$ & $\begin{array}{c}33,1 \\
\%\end{array}$ \\
\hline 2012 & 4,4 & 1,9 & $\begin{array}{c}62,4 \\
\%\end{array}$ & $8,0 \%$ & $\begin{array}{c}14,6 \\
\%\end{array}$ & $\begin{array}{c}25,5 \\
\%\end{array}$ \\
\hline 2013 & 4,1 & 1,8 & $\begin{array}{c}63,6 \\
\%\end{array}$ & $5,2 \%$ & $8,9 \%$ & $\begin{array}{c}16,3 \\
\%\end{array}$ \\
\hline 2014 & 4,1 & 1,6 & $\begin{array}{c}63,5 \\
\%\end{array}$ & $4,7 \%$ & $7,3 \%$ & $\begin{array}{c}14,5 \\
\%\end{array}$ \\
\hline 2015 & 4,5 & 1,7 & $\begin{array}{c}62,3 \\
\%\end{array}$ & $1,0 \%$ & $2,0 \%$ & $4,1 \%$ \\
\hline $\begin{array}{c}\text { Rata- } \\
\text { rata }\end{array}$ & $\mathbf{4 , 3}$ & $\mathbf{1 , 8}$ & $\begin{array}{c}\mathbf{6 2 , 8} \\
\mathbf{\%}\end{array}$ & $\begin{array}{c}\mathbf{5 , 4} \\
\mathbf{\%}\end{array}$ & $\begin{array}{c}\mathbf{1 0 , 1} \\
\mathbf{\%}\end{array}$ & $\begin{array}{c}\mathbf{1 8 , 7} \\
\mathbf{\%}\end{array}$ \\
\hline
\end{tabular}

Penilaian Rata-rata Rasio

Profitabilitas PT. Fast Food

Indonesia Tbk dengan Rata-rata

Industri Tahun 2011 s.d 2015

\begin{tabular}{|l|c|c|l|}
\hline \multicolumn{1}{|c|}{ RASIO } & $\begin{array}{c}\text { RATA- } \\
\text { RATA } \\
\text { PERUSA } \\
\text { HAAN }\end{array}$ & $\begin{array}{c}\text { RATA- } \\
\text { RATA } \\
\text { INDUST } \\
\text { RI }\end{array}$ & $\begin{array}{c}\text { ANALI } \\
\text { SA }\end{array}$ \\
\hline $\begin{array}{l}\text { Gross Profit } \\
\text { Margin }\end{array}$ & $59,6 \%$ & $62,8 \%$ & $\begin{array}{l}\text { Kurang } \\
\text { Baik }\end{array}$ \\
\hline Net Profit Margin & $4,6 \%$ & $5,42 \%$ & $\begin{array}{l}\text { Kurang } \\
\text { Baik }\end{array}$ \\
\hline $\begin{array}{l}\text { Return on } \\
\text { Investment }\end{array}$ & $9,2 \%$ & $10,1 \%$ & $\begin{array}{l}\text { Kurang } \\
\text { Baik }\end{array}$ \\
\hline Return on Equity & $17,7 \%$ & $18,7 \%$ & $\begin{array}{l}\text { Kurang } \\
\text { Baik }\end{array}$ \\
\hline
\end{tabular}

1) Gross Profit Margin (GPM)

Nilai GPM PT. Fast Food Indonesia Tbktahun 2011 s.d 2015 dikatakankurangbaikkarenaselama 5 (lima) periodetersebut GPM perusahaanberturut-turutberada di bawah rata-rata industri. Rata-rata GPM PT. Fast Food Indonesia Tbk periode 2011 s.d 2015 kurang baik karena berada di bawah rata-rata industri yaitu sebesar 59,6 \% sedangkan GPM rata-rata industri sebesar $62,8 \%$. Nilai GPM PT. Fast Food Indonesia Tbk yang berada di bawah rata-rata industri menunjukkan bahwa perusahaan belum mampu melakukan efisiensi secara optimal pada beban pokok penjualandibandingkan perusahaan lainnya.

2) Net Profit Margin (NPM)

NPM PT. Fast Food Indonesia Tbktahun $2011 \quad$ s.d 2014 kurangbaikkarenaberturutturutberada di bawah rata-rata industri, namunpadatahun 2015 NPM

perusahaanmenunjukkankondisibai kkarenaberada di atas rata-rata industri. Nilai rata-rata NPM PT. Fast Food Indonesia Tbk periode 2011 s.d 2015 sebesar 4,6\% dikatakan kurang baik karena 




berada di bawah rata-rata industri, dimana NPM rata-rata industri adalah sebesar $5,42 \%$. Nilai NPM PT. Fast Food Indonesia Tbk yang berada di bawah rata-rata industri menunjukkan bahwa disamping perusahaan belum optimal dalam melakukan efisiensi terhadap beban pokok penjualan juga dikarenakan kurang efisiennya pada pengelolaan beban operasional sehingga penerimaan laba bersih menjadi lebih rendah.

3) Return on Investment (ROI)

ROI PT. Fast Food Indonesia Tbktahun $2011 \quad$ s.d 2014 kurangbaikkarenaberturutturutberada di bawah rata-rata industri, namunpadatahun 2015 ROI

perusahaanmenunjukkankondisibai kkarenaberada di atas rata-rata industri. Nilai rata-rata ROI PT. Fast Food Indonesia Tbk periode 2011 s.d 2015 dikatakan kurang baik karena berada di bawah ratarata industri yaitu sebesar 9,2\% sedangkan ROI rata-rata industri sebesar $10,1 \%$. Sekalipun perusahaan telah efektif dalam melakukan perputaran total asset, namun tingginya beban operasi menyebabkan penerimaan laba bersih menjadi lebih sedikit. Hal ini menunjukan bahwa perusahaan belum mampu melakukan efisiensi dibandingkan dengan perusahaan lain.

4) Return on Equity (ROE)

ROE PT. Fast Food Indonesia Tbktahun $2011 \quad$ s.d 2013 kurangbaikkarenaberturutturutberada di bawah rata-rata industri, namunpadatahun 2014

dan 2015 ROI perusahaanmenunjukkankondisibai kkarenaberada di atas rata-rata industri. Nilai rata-rata ROE PT. Fast Food Indonesia Tbk kurang baik bila dibandingkan dengan rata-rata industri, yaitu sebesar $17,7 \%$ sedangkan ROE rata-rata industri sebesar $18,7 \%$. Tingkat ROE perusahaan yang berada di bawah rata-rata industri menunjukkan bahwa setiap modal yang digunakan menghasilkan keuntungan yang lebih kecil jika dibandingkan dengan rata-rata industri.

\section{KESIMPULAN DAN SARAN}

A. Kesimpulan

1. Rasio Aktivitas PT. Fast Food Indonesia, Tbk.

Rasio aktivitas PT. Fast Food Indonesia Tbk dari tahun 2011 sampai dengan tahun 2015 mengalami kenaikan dan penurunan. Perputaran Modal Kerja (Working Capital Turn Over) perusahaan mengalami kenaikan yaitu diketahui sebanyak 4,2 kali pada tahun 2011, sebanyak 4,4 kali pada tahun 2012, sebanyak 4,3 kali pada tahun 2013, sebanyak 4,5 kali pada tahun 2014 , dan sebanyak 4,5 kali pada tahun 2015.

Sedangkan Perputaran Total Asset (Total Assets Turn Over) perusahaan mengalami penurunan dari tahun 2011 sampai dengan 2015. Perputaran Total Asset diketahui sebanyak 2,1 kali pada tahun 2011, sebanyak 2 kali pada tahun 2012, sebanyak 2 kali pada tahun 2013, sebanyak 1,9 kali pada tahun 2014, dan sebanyak 1,9 kali pada tahun 2015. Penurunan 




perputaran total asset perusahaan disebabkan oleh kenaikan total asset yang kurang diimbangi dengan kenaikan penjualan.

\section{Rasio Profitabilitas PT. Fast Food Indonesia, Tbk.}

\section{Kinerja Keuangan PT. Fast Food Indonesia, Tbk.}

Kinerja keuangan PT. Fast Food Indonesia Tbk tahun 2011 sampai dengan tahun 2015 berdasarkan rasio aktivitas dapat dikatakan baik karena berada di atas rata-rata Rasio profitabilitas PT. Fast Food Indonesia Tbk dari tahun 2011 sampai dengan tahun 2015 mengalami kenaikan dan penurunan. Indikator rasio profitabilitas dengan rata-rata mengalami kenaikan terjadi pada Gross Profit Margin (GPM), sedangkan indikator rasio profitabilitas pada Net Profit Margin (NPM), Return on Investment (ROI) dan Return on Equity (ROE) mengalami penurunan. Nilai Gross Profit Margin (GPM) diketahui sebesar $58,9 \%$ pada tahun 2011, 58,5\% pada tahun $2012,59,3 \%$ pada tahun 2013, 60,4\% pada tahun 2014, dan $60,9 \%$ pada tahun 2015 .

Net Profit Margin (NPM) diketahui sebesar $7,2 \%$ pada tahun $2011,5,8 \%$ pada tahun $2012,3,9 \%$ pada tahun $2013,3,7 \%$ pada tahun 2014, dan 2,3\% pada tahun 2015 . Selanjutnya Return on Investment (ROI) diketahui sebesar $14,8 \%$ pada tahun $2011,11,6 \%$ pada tahun $2012,7,7 \%$ pada tahun $2013,7,2 \%$ pada tahun 2014 , dan $4,5 \%$ pada tahun 2015. Kemudian Return on Equity (ROE) diketahui sebesar $27,6 \%$ pada tahun 2011, 20,8\% pada tahun $2012,15,9 \%$ pada tahun 2013, 14,8\% pada tahun 2014, dan 9,4\% pada tahun 2015 .

Modal Kerja (Working Capital Turn Over) perusahaan untuk 5 periode tersebut sebanyak 4,4 kali sedangkan rata-rata industri 4,3 kali, dimana WCTO perusahaan pada tahun 2011 menunjukan kondisi yang kurang baik, tahun 2012 cukup baik, tahun 2013 dan 2014 pada kondisi baik, dan tahun 2015 pada kondisi yang cukup baik. Selanjutnya rata-rata Perputaran Total Asset (Total Assets Turn Over) perusahaan sebanyak 2 kali sedangkan rata-rata industri sebanyak 1,8 kali, dimana TATO perusahaan pada tahun 2011 menunjukan kondisi yang cukup baik, dan pada tahun 2012 s.d 2015 menunjukan kondisi yang baik.

Berdasarkan rasio profitabilitas, kinerja keuangan PT. Fast Food Indonesia Tbk tahun 2011 sampai dengan tahun 2015 dapat dikatakan kurang baik bila dibandingkan dengan rata-rata industri. Nilai ratarata untuk 4 (empat) indikator rasio profitabilitas yang digunakan pada penelitian ini selama 5 (lima) periode tersebut menunjukan hasil perhitungan yang berada dibawah rata-rata industri yaitu untuk nilai GPM perusahaan sebesar 59,6\% sedangkan rata-rata industri sebesar $62,8 \%$, nilai NPM perusahaan sebesar $4,6 \%$ sedangkan rata-rata industri $5,42 \%$, nilai ROI 


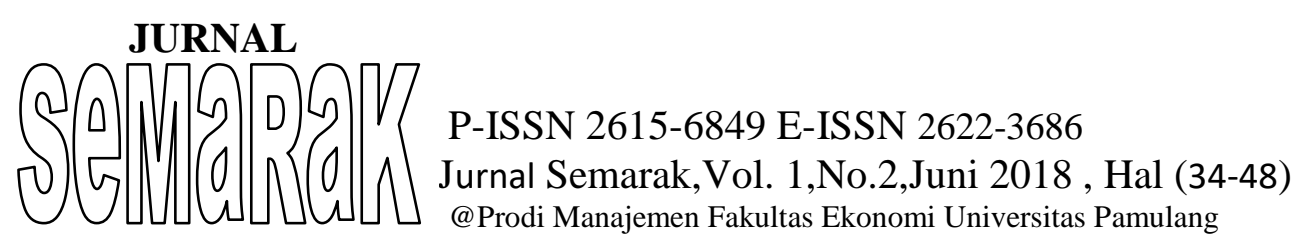

perusahaan sebesar $9,2 \%$ sedangkan rata-rata industri $10,1 \%$, dan ROE perusahaan sebesar $17,7 \%$ sedangkan rata-rata industri $18,7 \%$.

Indikator GPM selama 5 (lima) periode menunjukan kondisi yang kurang baik karena berturutturut berada di bawah rata-rata industri. Selanjutnya NPM dan ROI menunjukan kondisi yang kurang baik pada tahun 2011 s.d 2014 namun menunjukan kondisi yang baik pada tahun 2015, terlihat bahwa NPM dan ROI rata-rata industry dan perusahaan selama 5 (lima) periode yang cenderung menurun, namun padatahun 2015 perusahaan lebih mampu bertahan disbanding perusahaan lainnya. Sedangkan ROE menunjukan kondisi yang kurang baik pada tahun 2011 s.d 2013 namun menunjukan kondisi yang baik pada tahun 2014 dan 2015, terlihat bahwa ROE rata-rata industry dan perusahaan selama 5 (lima) periode yang cenderung menurun, namun padatahun 2015 perusahaan lebih mampu bertahan disbanding perusahaan lainnya.

\section{B. Saran.}

Berdasarkan hasil penelitian ini, diketahui bahwa kinerja keuangan PT. Fast Food Indonesia Tbk tahun 2011 sampai dengan 2015 berdasarkan rasio aktivitas baik, namun kurang baik berdasarkan rasio profitabilitas. Hal ini menunjukan bahwa perusahaan telah efektif dalam memanfaatkan sumber daya yang dimilikinya dibandingkan dengan perusahaan lain yang sejenis. Namun kondisi profitabilitas perusahaan kurang

\section{DAFTAR PUSTAKA}

Brigham dan Houston, "Dasar-dasar Manajemen Keuangan", Edisi 11, Buku 1, Jakarta: Salemba Empat, 2010.

Ekawati, Erni, "Manajemen Keuangan", Edisi 1, Cetakanketiga,

Jakarta:Universitas Terbuka, 2009.

Hery, "AnalisisLaporanKeuangan", CetakanKedua, Jakarta:Grasindo, 2017. 


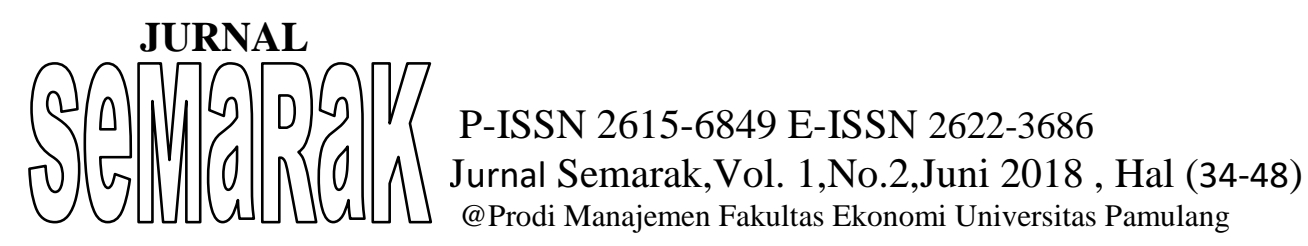

Husnan,

Suad,

JurnalAdministrasiBisnis, Vol.

"MateriPokokManajemen

37 no. 1, 2016: 121-128.

Keuangan", EdisiKedua, Prihadi,

Cetakankeenam,

Jakarta:Universitas Terbuka, 2011.

Irham, "ManajemenKinerja, Riyanto,

Teori dan Aplikasi",

Bandung: Alfabeta, 2010.

Hanafi, Mamduh M. dan Abdul Halim,

"AnalisisLaporanKeuangan",

EdisiKeempat, CetakanKedua,

Yogyakarta: UPP STIM

YKPN, 2012.

Hasibuan,

Malayu

S.P

"ManajemenSumberDayaManu

sia", Jakarta: BumiAksara, 2011.

Horne, James C. Van dan John M. of Financial Management, 12

Edition",

Jakarta:

SalembaEmpat, 2009.

IkatanAkuntansi Indonesia, "PSAK

No.1

PenyajianLaporanKeuangan

(Revisi

2009)",

Jakarta:DewanAkuntansi

Indonesia, 2009.

Jumingan,

“AnalisisLaporanKeuangan",

Jakarta: BumiAksara, 2011.

Kasmir, "Analisis Laporan Keuangan",

Edisi 1, Cetakan 9, Jakarta:

Rajawali Pers, 2016.

"Pengantar

ManajemenKeuangan", Edisi

1, Cetakan 3, Jakarta: Kencana, 2010.

Lustiana,

Maya,

NengahSudjanadanAchmadHu

saini,

"PenggunaanAnalisisRasioKe

uanganuntukMenilaiKinerjaKe

uangan

Perusahaan",

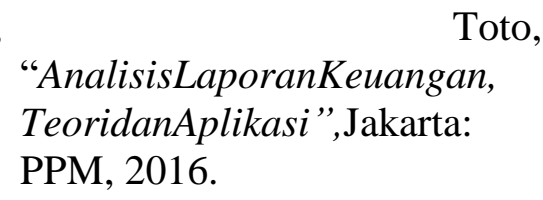

Bambang,

"Dasar-

dasarPembelanjaan

Perusahaan", Edisikeempat, Yogyakarta: BPPE, 2013.

Robbins, Stephen P. dan Mary Coulter, "Manajemen"

EdisiKesepuluh,

Jakarta:Erlangga, 2010.

Subramanyam, K.R, "AnalisisLaporanKeuangan", Edisi 11, Buku 1, Jakarta:SalembaEmpat, 2017.

Sugiyono, "Metode Penelitian Kuantitatif, Kualitatif, dan $R \& D ”$, Bandung: Alfabeta, 2011.

Sukmadinata, Nana Syaodih, "Metode Penelitian Pendidikan", Bandung:RemajaRosdakarya, 2012.

Sulistyo-Basuki, "Metode Penelitian", Cetakan Kedua, Jakarta: Penaku, 2010.

Supriyatna, DadangdanAndiSylvana, "MateriPokokManajemen"

CetakanKeempat, Jakarta:Universitas Terbuka, 2011.

Sutrisno,

"ManajemenKeuanganTeoriK onsep\&Aplikasi”,

CetakanKesembilan,

Yogyakarta:Ekonisia, 2013.

Martias, Andi, "AnalisisKinerjaKeuangan Perusahaan

PendekatanRasioPenentu di Bursa Efek Indonesia”, 
JURNAL

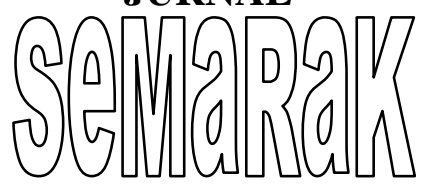

P-ISSN 2615-6849 E-ISSN 2622-3686

Jurnal Semarak,Vol. 1,No.2,Juni 2018 , Hal (34-48)

@ Prodi Manajemen Fakultas Ekonomi Universitas Pamulang

JurnalMoneter, Vol. IV no. 2, 2017: 99-105.

Nurhamdi, Muhamad, "Analisis Kinerja Keuangan

Berdasarkan Rasio

Profitabilitas pada PT. Fast

Food Indonesia Tbk tahun 2009 s.d 2013”, Skripsi, Universitas Pamulang, Tangerang Selatan, 2015.

Rahardjo, Budi Tri danRiaMurdani, "PengaruhKinerjaKeuangand anPengungkapan Corporate Social Responsibility terhadapNilai Perusahaan", JurnalAkuntansidanBisnisKris nadwipayana, Vol. 03 no. 01, $2016: 1-9$.

http://www.idx.co.id/id-

id/beranda/perusahaantercatat/l aporankeuangandan

tahunan.aspx (diakses pada tanggal 22/05/2017 jam 14.41 WIB)

http://ekonomi.kompas.com/read/2016/ $\underline{\text { 02/07/182803626/Pertumbuha }}$ n.Ekonomi.2015.Terendah.dal am.Enam.Tahun.Terakhir/

(diaksespadatanggal 29/05/2017 pkl 07.00 WIB)

http://www.kompasiana.com/relawanht/ minim-kontribusi-padapertumbuhan-ekonomi-iniyang-harus-dilakukanpemerintah(diakses pada tanggal 29/05/2017 Pkl. 07.05 WIB)

http://www.kfcindonesia.com/kegiatanusaha-perusahaan (diakses pada tanggal 22/05/2017 jam 15.30 WIB). 